\title{
Effects of growth regulator and nitrogen on yield and lodging of irrigated wheat
}

\section{Regulador de crescimento e nitrogênio no desempenho produtivo e acamamento do trigo irrigado}

\author{
Pedro Henrique Marques Paula Nunes ${ }^{1}$; Leonardo Angelo de Aquino ${ }^{2 *}$; \\ Felipe Oliveira Xavier'; Luiz Paulo Dornelas dos Santos ${ }^{3}$; \\ Lucas Gonçalves Machado ${ }^{3}$; Priscila Maria de Aquino ${ }^{4}$
}

\begin{abstract}
High rates of nitrogen $(\mathrm{N})$ increase plant growth, which can result in lodging. To avoid excessive growth of plants, plant growth regulators (PGRs), which cause internode length reduction, can be used. In this study, our objective was to evaluate the $\mathrm{N}$ nutritional status, growth, and yield of irrigated wheat as parameters using variable rates of nitrogen and growth regulator. Two experiments were conducted in Rio Paranaíba - MG in 2011 and 2012 using the BRS 264 cultivar. The treatments consisted of two concentrations of $\mathrm{N}$ (50 and $110 \mathrm{~kg} \mathrm{ha}^{-1}$ as urea) and five concentrations of the growth regulator trinexapac-ethyl $\left(0,0.2,0.4,0.6\right.$, and $0.8 \mathrm{~L} \mathrm{ha}^{-1}$ of Moddus ${ }^{\circledR}$ containing $25 \% \mathrm{w} / \mathrm{v}$ of trinexapac-ethyl). Each plot consisted of 20 rows of wheat spaced $0.17 \mathrm{~m}$, six meters in length. We evaluated plant height, shoot dry matter accumulation, thousand-grain weight, number of grains per spike, yield, leaf $\mathrm{N}$ content in the index leaf and grain, amount of $\mathrm{N}$ uptake and export, and lodging index. The PGR resulted in a linear decrease in plant height and shoot dry matter production. However, the rates of the growth regulator did not affect productivity. The rates of $\mathrm{N}$ influenced the yield only in 2011 .
\end{abstract}

Key words: Trinexapac-ethyl. Triticum aestivum L. Plant growth regulators. Harvest index.

\section{Resumo}

Elevada disponibilidade de nitrogênio $(\mathrm{N})$ propicia melhores condições de crescimento e produtividade de grãos, mas podem aumentar a ocorrência do acamamento de plantas em trigo. Uma das opções para evitar o elevado crescimento das plantas e, consequentemente o acamamento, é o uso de reguladores de crescimento, que reduzem o comprimento dos entrenós. Neste trabalho, objetivou-se avaliar o estado nutricional de $\mathrm{N}$, o crescimento de plantas e o desempenho produtivo do trigo irrigado em resposta a doses de $\mathrm{N}$ e de regulador de crescimento. O experimento foi realizado em Rio Paranaíba - MG, em duas safras agrícolas, com a cultivar BRS 264. Os tratamentos consistiram de duas doses de N (50 e $\left.110 \mathrm{~kg} \mathrm{ha}^{-1}\right)$, aplicadas via ureia e, de cinco doses de regulador de crescimento trinexapac-ethyl $(0 ; 0,05$; 0,$1 ; 0,15$ e $\left.0,2 \mathrm{~kg} \mathrm{ha}^{-1}\right)$. Cada parcela foi constituída por 20 fileiras de trigo, espaçadas de $0,17 \mathrm{~m}$, com seis metros de comprimento. Foram avaliados a altura de plantas, o acúmulo de matéria seca da parte aérea, a massa de mil grãos, o número de grãos por espiga, a produtividade de grãos, o teor de $\mathrm{N}$ na folha

${ }^{1}$ Eng $^{\mathrm{o}}$ Agr $^{\circ}$, Universidade Federal de Viçosa, UFV, Campus Rio Paranaíba, Rio Paranaíba, MG, Brasil. E-mail: pedronunes.ufv@ gmail.com

2 Eng ${ }^{\circ}$ Agr $^{\circ}$, Prof. Dr., UFV, Campus Rio Paranaíba, Rio Paranaíba, MG, Brasil. E-mail: leonardo.aquino@ufv.br

3 Eng ${ }^{o s}$ Agros, Discentes do Curso de Mestrado do Programa de Pós-Graduação em Agronomia, Produção Vegetal, UFV, Campus Rio Paranaíba, Rio Paranaíba, MG, Brasil. E-mail: felipe.o.xavier@ufv.br; luiz.dornelas@ufv.br; lucas.g.machado@ufv.br

4 Discente do Curso de Graduação em Agronomia, UFV, Campus Rio Paranaíba, Rio Paranaíba, MG, Brasil. E-mail: priscila. maria@ufv.br

* Author for correspondence 
índice e nos grãos, a quantidade do $\mathrm{N}$ absorvido e exportado e o índice de acamamento. O regulador proporcionou decréscimo linear na altura de plantas e na produção de matéria seca da parte aérea, sem incrementar a produtividade de grãos. $\mathrm{O} \mathrm{N}$ incrementou a produtividade de grãos apenas no ano de 2011. Não há interação entre doses de $\mathrm{N}$ e de reguladores de crescimento para o trigo irrigado cultivado em sucessão a soja e a cenoura.

Palavras-chave: Trinexapac-ethyl. Triticum aestivum L. Reguladores vegetais. Índice de colheita.

\section{Introduction}

The region of Alto Paranaíba - MG, Brazil, includes areas with altitudes above $800 \mathrm{~m}$ with an average annual temperature of $20.4^{\circ} \mathrm{C}$, good water availability, and soils suitable for agriculture (NOVAIS, 2011). These conditions make this region a major production center for vegetables, among other crops. During winter, wheat is cultivated because it is well adapted to this region, has low water requirements, and is an important crop to use during crop rotation.

Sowing of wheat may occur between February and March (dryland wheat) to take advantage of the rainy season and can occur between April and May under irrigation. It is often grown following the harvest of soybean or vegetable crops. Vegetable and legumes provide high residual levels of nutrients in the soil, especially nitrogen $(\mathrm{N})$, which, together with the favorable climate and irrigation, facilitates the high productive potential of wheat. Residual soil $\mathrm{N}$ can be used by subsequent crops, which reduces the cost of fertilizers (NUNES et al., 2015).

The level of $\mathrm{N}$ is positively associated with the number of tillers and the formation and elongation of nodes, which allows more solar radiation to be harnessed, and consequently, a greater yield of grain (MEGDA et al., 2009; RODRIGUES et al., 2014). However, high concentrations of $\mathrm{N}$ can increase the risk of lodging of wheat plants, particularly under strong winds. Lodging can reduce wheat quality because the leaves and spikes of the lodged plant are closer to the ground, and consequently in a moister environment, which can reduce the quality of grains (ZAGONEL; FERNANDES, 2007). In addition, lodging can increase self-shading and hinder the translocation of assimilated nutrients. The intensity of the damage depends on the phenological stage. Lodging also hinders mechanized harvest and can decrease the productivity of wheat (PAGLIOSA et al., 2013).

Lodging can be efficiently controlled through the restriction of nitrogen fertilizers and the use of shorter stem genotypes with increased tolerance to lodging (PENCKOWSKI et al., 2010). Nevertheless, most productive cultivars are responsive to $\mathrm{N}$ and are sensitive to lodging. Therefore, the use of growth regulators is important because they can reduce plant height, even when treated with high doses of $\mathrm{N}$, which results in high yields.

Hormonal balance has a direct relationship with the production potential of a crop. In wheat, the balance between auxins and cytokinins is decisive for the issuance of tillers, and directly affects the components of grain that define production (VALÉRIO et al., 2009). An increase in the endogenous activity of gibberellins results in the elongation of the culm (TAIZ; ZEIGER, 2009) and affects the ability of plants to accumulate reserves and resist lodging (CRUZ et al., 2001). This underlines the importance of working with products that inhibit the synthesis of gibberellin to reduce of plant growth.

Trinexapac-ethyl is one of the most commonly used growth regulators. It acts in plants by reducing cellular elongation in the vegetative stage. At the end of the metabolic biosynthesis pathway of gibberellic acid (RAJALA, 2003), it inhibits the enzyme $3 \beta$-hydroxylase, which dramatically reduces the level of active gibberellic acid $\mathrm{GA}_{1}$, and thus increases its immediate biosynthetic precursor $\mathrm{GA}_{20}$ (DAVIES, 1987). The reduction in the concentration of $\mathrm{GA}_{1}$ is the probable cause of the decrease in plant growth (RADEMACHER, 2000). 
In this context, it is important to conduct studies that elucidate the influence of growth regulators on wheat treated with $\mathrm{N}$ in an effort to achieve high wheat yields. Thus, the goal of this study was to evaluate the nutritional status of $\mathrm{N}$, the growth of plants, and the production performance of irrigated wheat treated with nitrogen and the growth regulator trinexapac-ethyl.

\section{Material and Methods}

The experiment was conducted in 2011 and 2012 in the experimental area of the Alto Paranaíba Agriculture Cooperative (COOPADAP), located in the municipality of Rio Paranaíba - $\mathrm{MG}$, $\left(19^{\circ} 12^{\prime} 21^{\prime \prime} \mathrm{S}\right.$ and $\left.46^{\circ} 10^{\prime} 05^{\prime \prime} \mathrm{W}\right)$, at an altitude of $1,140 \mathrm{~m}$. The climate, according to the International Köppen Classification, was type Aw, defined as tropical with a dry season. The soil was classified as red-yellow latosol, with clayey texture.

Cultivation occurred in areas with high residual soil $\mathrm{N}$ caused by prior cultivation with soybeans (2011) and carrots (2012); soybeans, being a legume, have symbiotic associations that allow the fixation of $\mathrm{N}_{2}$. Because of the high quantities of applied $\mathrm{N}$ that remained in the soil, carrots were planted quickly as subsequent crops. The wheat was irrigated by a center pivot system and the daily water level was restored based of the estimated evapotranspiration according during the phases of cultivation and evaporation rate in a class A tank near the cultivation area.

The treatments consisted of two doses of $\mathrm{N}$ (50 and $\left.110 \mathrm{~kg} \mathrm{ha}^{-1}\right)$ and five doses of trinexapac-ethyl growth regulator $(0,0.05,0.1,0.15$, and $0.2 \mathrm{~kg}$ ha$\left.{ }^{1}\right)$. The product Moddus $($, which contains $25 \% \mathrm{w} / \mathrm{v}$ of trinexapac-ethyl, was used. The treatments were arranged in a split plot design. The doses of the growth regulator were arranged in the plots and the doses of $\mathrm{N}$ in the subplots. The experimental design was randomized blocks with four replicates.

The regulator was applied at the stage between the first and the second noticeable node from the plant, with the use of a $\mathrm{CO}_{2}$ pressurized costal spray. An XR 11002 (fine drop) tip was used, with a pressure of 3 bars and flow of $200 \mathrm{Lha}^{-1}$, and the growth regulator a systemic product.

Each experimental unit was composed of 20 cultivation rows, spaced $0.17 \mathrm{~m}$, being 6 meters in length. The 16 central rows were considered, eliminating a meter at each end. In both years, the sowing of wheat (BRS 264 cultivar) occurred in April with a resultant density of 270 plants $\mathrm{m}^{-2}$. The BRS 264 cultivar is indicated for cultivation in the Cerrado with a production potential of over $6,500 \mathrm{~kg} \mathrm{ha}^{-1}$, an approximate cycle of 50 days until emergence and 110 days to harvest, and an average height of $90 \mathrm{~cm}$ (ALBRECHT et al., 2006).

Soil samples were collected from the cultivation areas for chemical analysis (Table 1). Fertilization followed the recommendations for the cultivation of wheat irrigated in Minas Gerais (FORNASIERI FILHO, 2008), with the exception of $\mathrm{N}$, for which the doses were pre-established in accordance with the treatments.

During the two years, the application of $\mathrm{N}$ was split, with $20 \mathrm{~kg} \mathrm{ha}^{-1}$ application during sowing and the remaining application at the initiation of the tillering stage. On both occasions, the source of applied $\mathrm{N}$ was urea $(44 \%$ of $\mathrm{N})$ and it was applied with phosphorus (70 $\mathrm{kg} \mathrm{ha}^{-1}$ of $\mathrm{P}_{2} \mathrm{O}_{5}$ ) and potassium (40 kg ha-1 of $\mathrm{K}_{2} \mathrm{O}$ ) at sowing. It was distributed by broadcasting on the surface of the soil, in the sidedressing application. Immediately after the distribution of urea in the coverage area, the area was irrigated with a $15-\mathrm{mm}$ water blade to incorporate the fertilizer. 
Table 1. The chemical characteristics of the soil in 2011 and 2012 in the $0-20 \mathrm{~cm}$ layer.

\begin{tabular}{|c|c|c|}
\hline \multirow{2}{*}{ Chemical Attributes } & \multicolumn{2}{|c|}{ Years of cultivation } \\
\hline & Harvest -2011 & Harvest -2012 \\
\hline $\mathrm{pH} \mathrm{H_{2 }} \mathrm{O}$ & 6.1 & 6.4 \\
\hline $\mathrm{OM}-\mathrm{g} \mathrm{kg}^{-1}$ & 45.2 & 36.0 \\
\hline $\mathrm{P}-\mathrm{mg} \mathrm{dm}^{-3}$ & 16.8 & 32.4 \\
\hline $\mathrm{P}-$ residual $\left(\mathrm{mg} \mathrm{L}^{-1}\right)$ & 9.2 & 9.2 \\
\hline $\mathrm{K}-\mathrm{mg} \mathrm{\textrm {dm } ^ { - 3 }}$ & 100 & 129 \\
\hline $\mathrm{Ca}^{+2}-\mathrm{cmol}_{\mathrm{cm}}^{-3}$ & 3.5 & 3.6 \\
\hline $\mathrm{Mg}^{+2}-\mathrm{cmol}_{\mathrm{c}}^{\mathrm{c}} \mathrm{dm}^{-3}$ & 0.6 & 1.9 \\
\hline $\mathrm{SB}-\mathrm{cmol}_{\mathrm{c}} \mathrm{dm}^{-3}$ & 4.3 & 5.8 \\
\hline $\mathrm{CTC}_{\text {(potential) }}-\mathrm{cmol}_{\mathrm{c}} \mathrm{dm}^{-3}$ & 7.9 & 9.0 \\
\hline $\mathrm{V}^{\text {(potental) }}-\%$ & 54.6 & 64.5 \\
\hline $\mathrm{B}-\mathrm{mg} \mathrm{dm^{-3 }}$ & 0.6 & 0.7 \\
\hline $\mathrm{Zn}-\mathrm{mg} \mathrm{dm} \mathrm{m}^{-3}$ & 2.3 & 7.4 \\
\hline $\mathrm{Fe}-\mathrm{mg} \mathrm{dm}^{-3}$ & 46.2 & 49.0 \\
\hline $\mathrm{Mn}-\mathrm{mg} \mathrm{dm}{ }^{-3}$ & 9.4 & 2.3 \\
\hline $\mathrm{Cu}-\mathrm{mg} \mathrm{dm}{ }^{-3}$ & 1.1 & 2.2 \\
\hline
\end{tabular}

$\mathrm{OM}$ - organic matter; $\mathrm{P}, \mathrm{K}, \mathrm{Zn}, \mathrm{Fe}, \mathrm{Mn}$, and $\mathrm{Cu}-$ Mehlich Extractor $-1 ; \mathrm{Ca}^{2+}, \mathrm{Mg}^{2+}-\mathrm{KCl}$ Extractor $1 \mathrm{~mol} \mathrm{~L}^{-1}$, $\mathrm{B}$ - Hot water.

Management of pests, diseases, and weeds was performed as recommended for the cultivation of irrigated wheat (FORNASIERI FILHO, 2008). Irrigation management was performed according to crop water demand in the Alto Paranaíba region.

The following variables were evaluated: plant height, grains per spike, thousand-grain weight, grain yield, shoot dry matter accumulation, $\mathrm{N}$ content in the leaf index and grains, $\mathrm{N}$ uptake, $\mathrm{N}$ exportation, and the lodging index.

The height of plants was evaluated near physiological maturity of the crop. Height was determined in 10 plants per experimental unit, measured from the soil to the apex of the spike, excluding the awns. The assessment of shoot dry matter accumulation of the plants was performed by collecting plants in one meter of a row. The plants were cut flush with the ground during the soft dough stage.

At the beginning of flowering, 50 index leaves were collected per experimental unit. This leaves correspond to those completely expanded below the spike (flag leaf) upon flowering (ARGENTA et al., 2001). The samples were dried in an oven with forced air ventilation at $70^{\circ} \mathrm{C}$ for $72 \mathrm{~h}$ and crushed in a Willey-type mill. The $\mathrm{N}$ content was quantified in accordance with the method described by Malavolta et al. (1997). From the $\mathrm{N}$ content and dry matter, the content of $\mathrm{N}$ in the shoot was calculated (N-uptake).

Harvest was manually performed 120 days after sowing. Ten spikes were taken at random per experimental unit to count the grains per spike. The percentage of lodged plants was evaluated by the ratio of the row lengths of lodged plants to the row lengths with erect plants. The plants were collected from $12 \mathrm{~m}$ of central rows (including the lodged plants) to determine the productivity of grains. The plants were threshed, the grain weighed, and the productivity calculated in $\mathrm{kg} \mathrm{ha}^{-1}$, with moisture corrected to $13 \%$ (wet basis). A sample of the harvested grains was collected to determine the dry mass of one-thousand grains by counting and weighing them on a $0.1 \mathrm{~g}$ precision balance. After the determination of mass, the grains were ground to quantify the $\mathrm{N}$ content of grains ( $\mathrm{N}$-exported), as described for the $\mathrm{N}$ accumulated in the shoot. 
The data were submitted to an analysis of variance (ANOVA). The degrees of freedom of the treatments were discriminated. An F test was performed to compare the doses of $\mathrm{N}$ and a regression analysis was conducted for the doses of the growth regulator. The level of significance was $5 \%$.

\section{Results and Discussion}

In both years, a significant interaction between the dosage of $\mathrm{N}$ and growth regulator was observed for the variables assessed; however, there was a significant isolated effect for each variable.
Plants height decreased linearly with the increase of growth regulator in both crop years (Figure 1A). The highest dose of regulator resulted in a reduction of 0.16 and $0.32 \mathrm{~m}$ in plant height compared to the control, in 2011 and 2012, respectively. In 2012, plant growth was higher, which might be attributed to more favorable growth conditions (in succession with carrots). In 2011, cultivation followed soybeans (providing a smaller residue of nutrients than carrots). The higher growth of plants in 2012 made the effect of the growth regulator in reducing plant size more evident.

Figure 1. Plant height (A) and shoot dry matter (B) of irrigated wheat according to the dosage of the growth regulator trinexapac-ethyl in the 2011 and 2012 harvests.
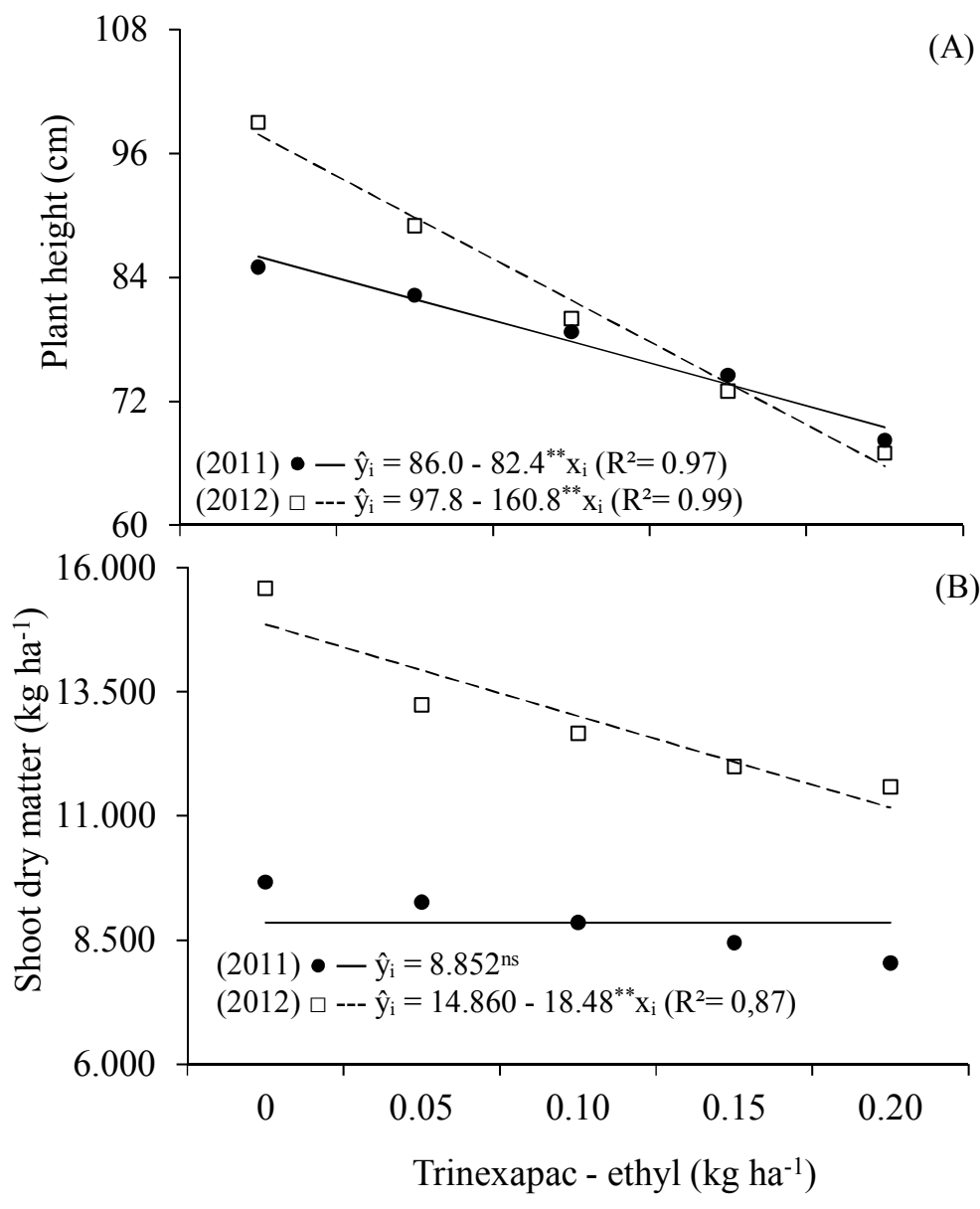

**, ns - significant at $1 \%$ and not significant at $5 \%$ by the $\mathrm{t}$ test, respectively. 
According to Zagonel et al. (2005) and Zagonel and Kunz (2005), growth regulators are effective in reducing the height of wheat plants, regardless of the size of the cultivar. Fioreze and Rodrigues (2014) observed that, even at different seeding densities, the application of trinexapac-ethyl promoted a reduction in the height of wheat plants. The authors also reported that the action of the regulator was more evident in inhibiting the biosynthesis of GA from the eighth day following the beginning of elongation.
Plant height increased with the dosage of $\mathrm{N}$ in 2011. However, in 2012, the $\mathrm{N}$ dosage did not affect plant height (Table 2). The greater height of plants grown in succession to carrots, independent of the doses of $\mathrm{N}$, was caused by the higher residue of nutrients in the soil, among them N. In addition to the carrot crop remnants, which have a low carbon/ nitrogen ratio $(\mathrm{C}: \mathrm{N})$ with rapid mineralization, the nitrogen content of the fertilizer applied to the crops was high and could leave considerable residual $\mathrm{N}$. These factors might have contributed to the greater availability of $\mathrm{N}$, which favored higher wheat growth.

Table 2. Plant height (PH), grains per spike (GRS), thousand-grain weight (TGW), productivity (PROD), shoot dry matter (SDM), content of $\mathrm{N}$ in the leaf index (ILN), content of $\mathrm{N}$ in grains (NGR), N-exported (NE), N-uptake (NU), and lodging (LODG) according to the dosage of $\mathrm{N}$.

\begin{tabular}{|c|c|c|c|c|c|c|c|c|c|c|}
\hline $\begin{array}{c}\text { Doses of N } \\
\mathrm{kg} \mathrm{ha}^{-1}\end{array}$ & $\begin{array}{l}\mathrm{PH} \\
\mathrm{cm}\end{array}$ & $\begin{array}{c}\text { GRS } \\
-\end{array}$ & $\begin{array}{c}\text { TGW } \\
\mathrm{g}\end{array}$ & $\begin{array}{l}\text { PROD } \\
\mathrm{kg} \mathrm{ha}^{-1}\end{array}$ & $\begin{array}{l}\text { SDM } \\
\mathrm{kg} \mathrm{ha}^{-1}\end{array}$ & $\begin{array}{l}\text { ILN } \\
\mathrm{g} \mathrm{kg}^{-1}\end{array}$ & $\begin{array}{l}\text { NGR } \\
\mathrm{g} \mathrm{kg}^{-1}\end{array}$ & $\begin{array}{c}\mathrm{NU} \\
\mathrm{kg} \mathrm{ha}^{-1}\end{array}$ & $\begin{array}{c}\mathrm{NE} \\
\mathrm{kg} \mathrm{ha}^{-1}\end{array}$ & $\begin{array}{c}\text { LODG } \\
\%\end{array}$ \\
\hline \multicolumn{11}{|c|}{ Harvest - 2011} \\
\hline 50 & 76.6 & 44.4 & 42.7 & 3,050 & 8,580 & 48.3 & 19.3 & 99.6 & 51.4 & 0 \\
\hline 110 & 79.0 & 42.7 & 42.5 & 3,726 & 9,122 & 52.3 & 20.4 & 121 & 66.1 & 0 \\
\hline Mean & 77.8 & 43.5 & 42.6 & 3,387 & 8,851 & 50.3 & 19.8 & 110 & 58.8 & 0 \\
\hline $\mathrm{F}$ & $10.4^{* *}$ & $3.9^{\mathrm{ns}}$ & $0.18^{\mathrm{ns}}$ & $25.6^{* *}$ & $1.2^{\mathrm{ns}}$ & $79.1^{* *}$ & $6.3^{*}$ & $8.5^{* *}$ & $26.9^{* *}$ & - \\
\hline C.V. & 3.0 & 6.2 & 3.1 & 12.5 & 17.5 & 2.8 & 6.5 & 20.6 & 15.2 & - \\
\hline \multicolumn{11}{|c|}{ Harvest -2012} \\
\hline 50 & 81.5 & 43.0 & 44.7 & 4,871 & 12,641 & 49.5 & 24.3 & 198 & 103 & 14.2 \\
\hline 110 & 82.1 & 42.0 & 43.8 & 4470 & 13,381 & 50.2 & 25.2 & 234 & 98.4 & 11.3 \\
\hline Average & 81.8 & 42.5 & 44.3 & 4.671 & 13,011 & 50.0 & 24.8 & 216 & 101 & 12.8 \\
\hline $\mathrm{F}$ & $0.2^{\mathrm{ns}}$ & $2.2^{\mathrm{ns}}$ & $0.4^{\mathrm{ns}}$ & $2.7^{\mathrm{ns}}$ & $1.3^{\mathrm{ns}}$ & $2.9^{\mathrm{ns}}$ & $7.6^{*}$ & $6.5^{*}$ & $0.8^{\mathrm{ns}}$ & $0.9^{\mathrm{ns}}$ \\
\hline C.V. & 6.0 & 6.7 & 4.5 & 16.7 & 15.9 & 2.3 & 4.2 & 20.7 & 17.2 & 72.2 \\
\hline
\end{tabular}

ns, ${ }^{* *}$ and ${ }^{*}$ - not significant, significant at 1 and $5 \%$ by the $\mathrm{F}$ test, respectively.

Zagonel et al. (2002a) and Marco Junior et al. (2013) observed that nitrogen fertilization increased the height of plants in cultivation under leguminous plants. However, Teixeira Filho et al. (2010) found no difference in height of wheat plants with increasing doses of $\mathrm{N}$. This author tested higher doses of $\mathrm{N}$ than Zagonel et al. (2002a) in a no-tillage system in succession to Poaceae cultivation, and the soil had less residual $\mathrm{N}$ from the preceding crop than that left by soybeans or carrots in the present study.

The production of shoot dry matter (SDM) was not influenced by the application of growth regulator in 2011, despite the reduction in height. This indicated that a greater thickening of leaves and accumulation of photoassimilates in the stem might have occurred, which accounted for the same dry matter with lower plant height. In 2012, SDM decreased linearly as a function of the application of trinexapac-ethyl (Figure 1B). The reduction of SDM with the growth regulator was not reflected in the grain yield. This implies a lower amount of nutrients invested in the vegetative part can obtain similar productivities, i.e. with application of the regulator, the plant was more efficient in converting 
assimilates into grain. These results are similar to those found by Fioreze and Rodrigues (2014).

The SDM was not influenced by the doses of $\mathrm{N}$ in both crop years (Table 2). In 2011, the mean SDM was $8,851 \mathrm{~kg} \mathrm{ha}^{-1}$ and in 2012 was $13,011 \mathrm{~kg} \mathrm{ha}^{-1}$. The discrepancy between the values $\left(4,160 \mathrm{~kg} \mathrm{ha}^{-1}\right)$ is caused by the difference in the residual nutrients in the soil, being higher in 2012 because of the prior cultivation of carrots, during which higher doses of fertilizer were applied (NUNES et al., 2015).

The number of grains per spike (GRS) and thousand grain weight (TGW) were not influenced by the dosage of $\mathrm{N}$ or dosage of the growth regulator in both years (Tables 2A, 2B, respectively). Similar results were obtained by Zagonel and Fernandes (2007), who observed no effect of trinexapacethyl on the number of grains per spike in three wheat cultivars. Penckowski et al. (2010) reported that despite the thousand-grain weight not being influenced by a growth regulator, its use increased the yield of grains, unlike the results observed in this study. Fioreze and Rodrigues (2014) obtained different results, and observed a decrease in thousand-grain weight with increases in trinexapacethyl, without influencing the productivity of wheat grains.

The highest dose of $\mathrm{N}$ resulted in a higher grain yield in the 2011 harvest, but did not influence the yield in 2012 (Table 2). The growth regulator did not significantly influence productivity (Figure 2C). The productivities for the mean doses of $\mathrm{N}$ tested were 3,387 kg ha-1 in 2011 and 4,671 kg ha $\mathrm{kg}^{-1}$ in 2012. Pagliosa et al. (2013) also found no differences in wheat productivity after soybean cultivation, fertilized with 60 or $120 \mathrm{~kg} \mathrm{ha}^{-1}$ of $\mathrm{N}$.
The absence of response in productivity to $\mathrm{N}$ in 2012 (Table 1) can be explained by the previous crop. In vegetable crops, including carrots, high doses of $\mathrm{N}$ are applied, which contribute to large residues of this nutrient for subsequent planting. Thus, the response to nitrogen fertilization of crops that succeeded vegetables might be low. The greater availability of $\mathrm{N}$ in the soil favors an increase in the number of tillers and grains per spike, which directly influences wheat productivity (MEGDA et al., 2009).

Prando et al. (2012) obtained a grain yield of $4,347 \mathrm{~kg} \mathrm{ha}^{-1}$ in soil with high residual $\mathrm{N}$, close to that achieved in this work. Zagonel et al. (2002b) observed that the application of trinexapac-ethyl increased the productivity of wheat grains. This increase in productivity was attributed to better targeting of assimilates towards grain production because of more compact plants. According to Penckowski and Fernandes (2010), changes in leaf architecture of wheat plants treated with growth regulator, especially in the angulation of the flag leaf that is more erect, can result in increased productivity. Similarly, Zagonal and Fernandes (2007) found no effect of growth regulator on the productivity of wheat.

The index leaf $\mathrm{N}$ content (ILN) was not influenced by the growth regulator in 2011. In 2012, there was a linear decrease in ILN with trinexapac-ethyl rates (Figure 3A). This might have occurred because of a greater translocation of $\mathrm{N}$ and photoassimilates to the grain in the beginning of the reproductive phase to fulfil requirements of new energy drains. Penckowski (2006) observed that the growth regulator did not affect the leaf $\mathrm{N}$ content of wheat cultivars, but interacted with the $\mathrm{N}$ doses applied. 
Figure 2. Grains per spike (A), thousand-grain weight (B), and grain yield (C) of wheat irrigated according to doses of the growth regulator trinexapac-ethyl in the 2011 and 2012 harvests.

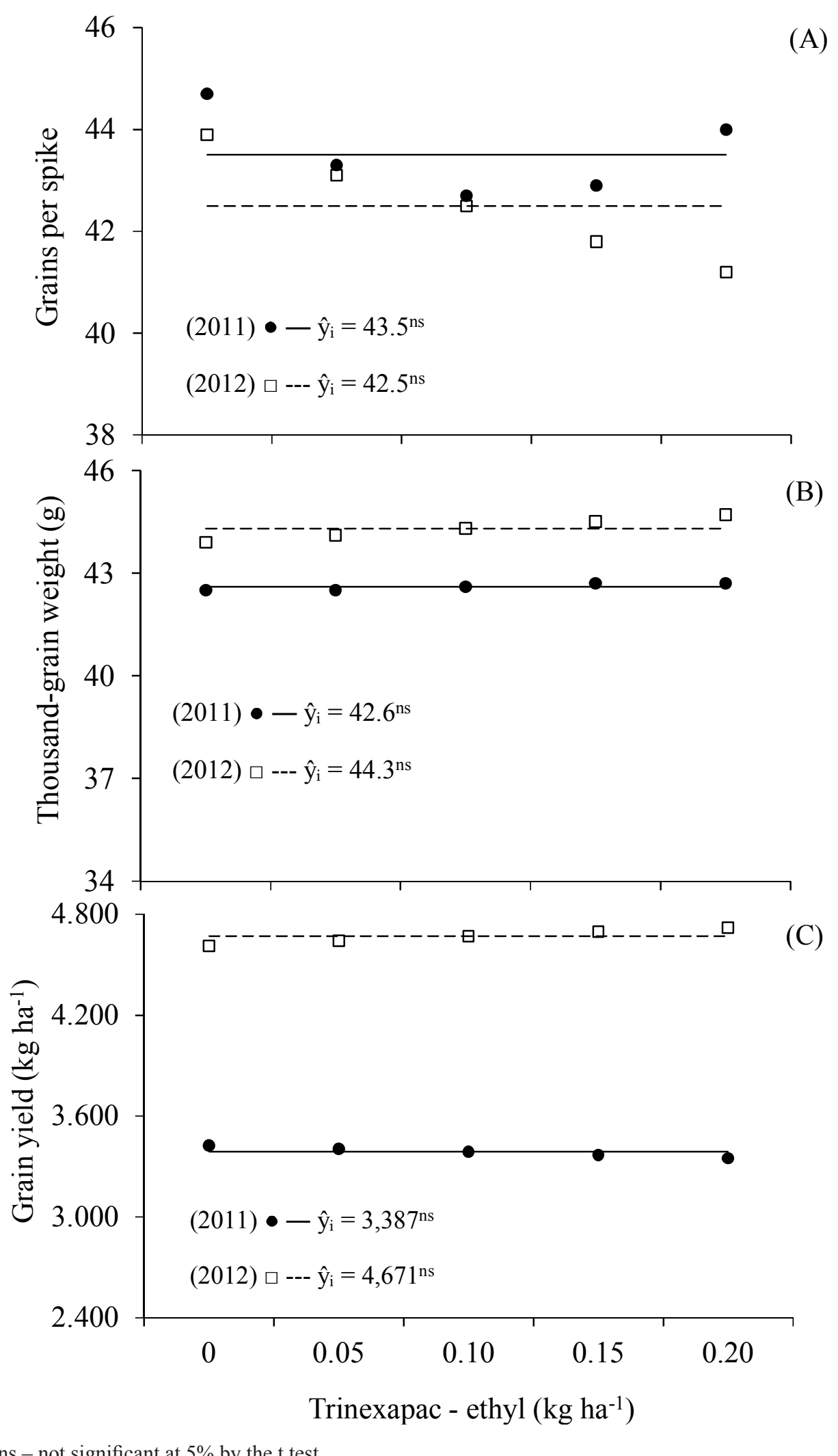

ns - not significant at $5 \%$ by the $t$ test. 
Figure 3. $\mathrm{N}$ content in index leaf and grains (A), $\mathrm{N}$ uptake and exported (B) in irrigated wheat according to doses of the growth regulator trinexapac-ethyl in the 2011 and 2012 harvests.

(A)

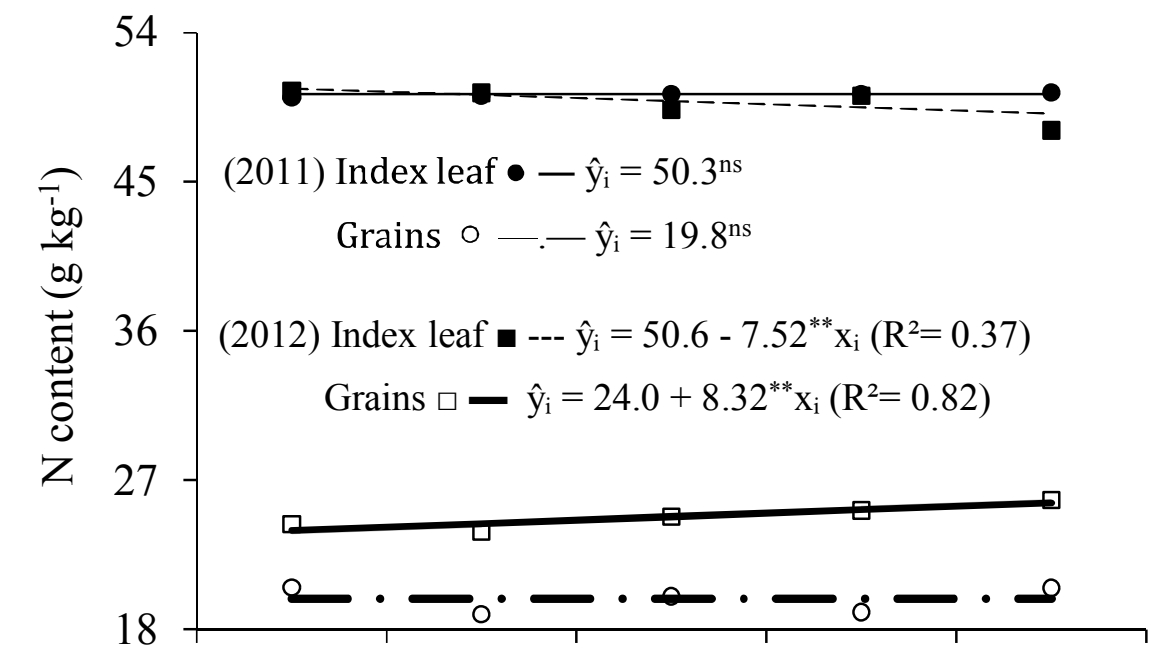

(B)

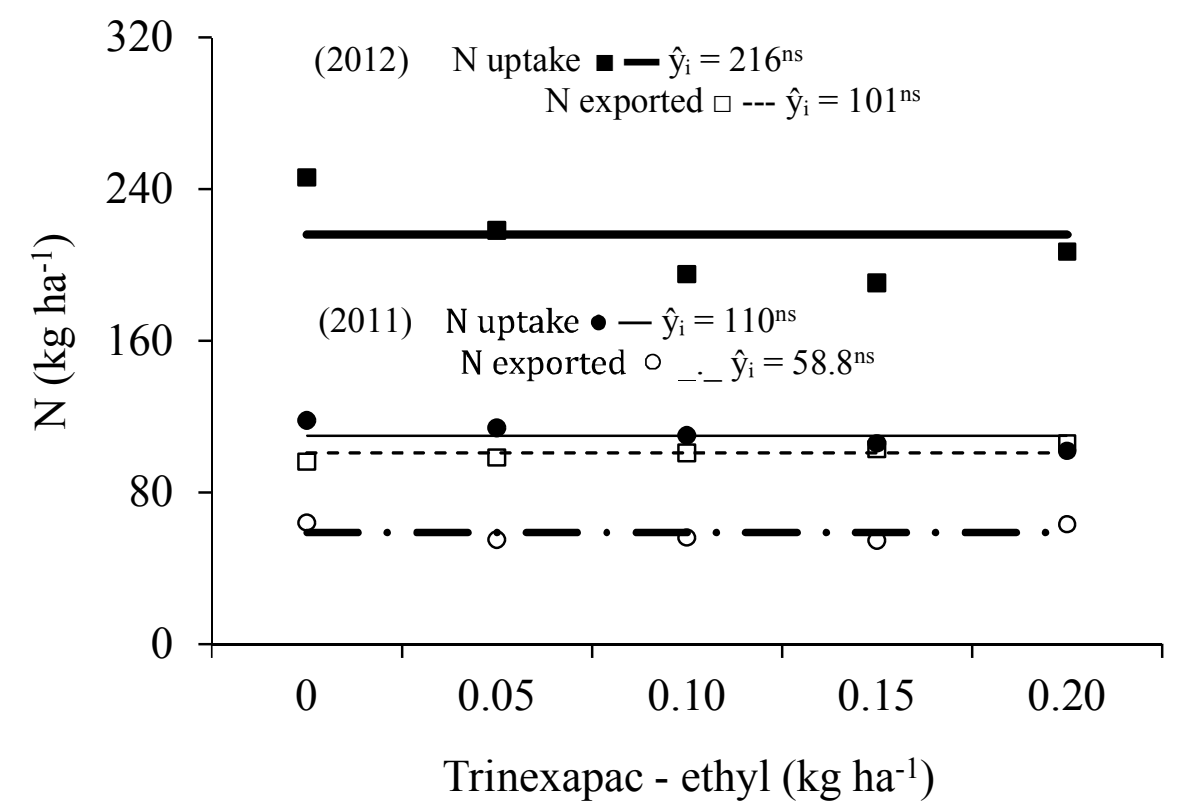

**, ns - significant at $1 \%$ and not significant at $5 \%$ by the $t$ test, respectively.

The ILN was influenced by the $\mathrm{N}$ doses only in 2011 (Table 2). In both years, $\mathrm{N}$ levels were higher than those obtained by Teixeira Filho et al. (2010) who studied doses, sources, and application seasons of $\mathrm{N}$ in irrigated wheat grown under a notillage system. The values observed were above the appropriate range and indicated a good supply of $\mathrm{N}$ to the plants and the high availability in soils.

The $\mathrm{N}$ content in grains (NGR) showed no response to the application of trinexapac-ethyl in 2011. However, in 2012 the NGR increased linearly with the dose of the growth regulator (Figure 3B). 
Fioreze and Rodrigues (2014) reported that this might have occurred because of a reduction in the distance of the main source (flag leaf) to the drain (spike), enabling a greater translocation of nutrients to the grains, increasing their content. According to these authors, the transport of carbohydrates between the source and the drain involves a series of metabolic processes; thus, the shortening of the distance between the leaf and the spike could result in an increase in the rate of translocation of assimilates to the grains, which directly influences the productivity of wheat. The NGR increased with the dose of $\mathrm{N}$ in both years of cultivation (Table 2), which corroborates the results obtained by Prando et al. (2012).

The N-uptake (NU) content of $\mathrm{N}$ in the shoot displayed no significant response to the regulator in both crop years (Figure 3B). The NU increased with the dose of $\mathrm{N}$ in both years of the experiment (Table 2). In 2011, the quantity of $\mathrm{N}$-uptake at a dose of $110 \mathrm{~kg} \mathrm{ha}^{-1}$ of $\mathrm{N}$ was $121 \mathrm{~kg} \mathrm{ha}^{-1}$. In 2012, this quantity, with the same dose of $\mathrm{N}$ applied, was 234 $\mathrm{kg} \mathrm{ha}^{-1}$. In both years, the quantities of the nutrient absorbed were higher than the amount applied via soil fertilization. This indicated a significant absorption of soil $\mathrm{N}$ (from mineralization of crop residues, organic matter, and residue of previous fertilization), especially in the second year of the experiment.

The $\mathrm{N}$-exported (NE) content of $\mathrm{N}$ in grains was not influenced by the use of the growth regulator in both years (Figure 3B). The NE was increased by $\mathrm{N}$ only in 2011 (Table 2). The greater availability of nutrients succeeding carrot cultivation generated greater productivity, content of $\mathrm{N}$ in grains, and consequently, NE.

No lodging of wheat plants occurred in the first year of the experiment; this may have occurred because of the small elongation of internodes of wheat plants, which led to a reduction in height of plants and low shoot dry matter accumulation. The low growth of the wheat internodes could be attributed to the smaller residual of nutrients in the soil ensued from the preceding soybean crop. In 2012, in which wheat was grown after carrots, a crop that leaves a large amount of nutrient residue in the soil, there was lodging of $64 \%$ of the plants in the experimental units that did not receive the growth regulator (Figure 4). The treatments that received the trinexapac-ethyl, regardless of the dose, did not present lodging of plants.

Figure 4. Lodging of irrigated wheat plants according to the presence of the growth regulator trinexapac-ethyl in the 2012 harvest.

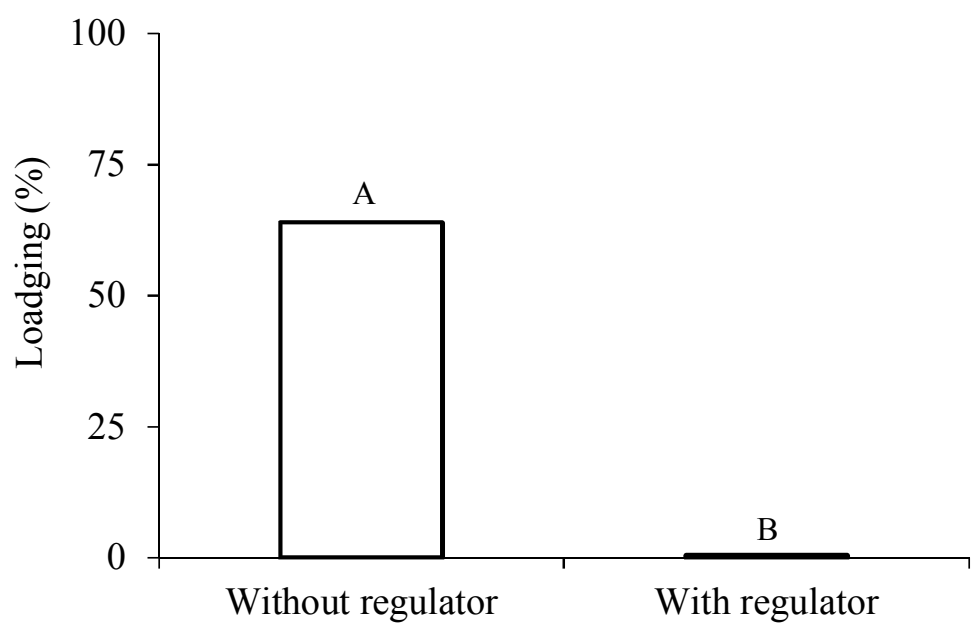


Lodging of plants was not influenced by the different rate of $\mathrm{N}$ (Table 2). Lodging of plants occurred with both $\mathrm{N}$ rates because of high residual $\mathrm{N}$ in the soil (2012 harvest). The $\mathrm{N}$ rate applied had a greater influence when the residual $\mathrm{N}$ in the soil was low. In a similar study, Penckowski et al. (2010) obtained a linear increase in the lodging of plants with $\mathrm{N}$. The lowest dose of the regulator $(0.05$ $\mathrm{kg} \mathrm{ha}^{-1}$ ) tested efficiently reduced the lodging index when the cultivation conditions were favorable to its occurrence (2012 harvest). In 2011, in which no lodging occurred, the greatest height of plants was estimated at $86 \mathrm{~cm}$. Thus, for the cultivar used (BRS 264), this height can be considered adequate for the control of lodging. In 2012, the dose of regulator needed to control height at $86 \mathrm{~cm}$ was $0.0725 \mathrm{~kg}$ ha ${ }^{-1}$ of trinexapac ethyl.

The higher doses of regulator had no influence on the productivity of grains. However, depending on the cultivar and the cultivation conditions, high doses could reduce productivity (ZAGONEL; FERNANDES, 2007). High doses of the regulator, if applied under conditions of water deficit, for example, could considerably reduce the vegetative growth, and also reduce productivity (PAGLIOSA et al., 2013). For the BRS 264 cultivar, when the previous crops provide high $\mathrm{N}$ in the soil and where weather conditions are satisfactory for growth, the rate of $0.0725 \mathrm{~kg} \mathrm{ha}^{-1}$ of trinexapac ethyl of the growth regulator resulted a plant height compatible with the control of lodging and grain productivity.

\section{Conclusions}

No interaction between doses of $\mathrm{N}$ and growth regulators in irrigated wheat grown in succession to soybeans and carrots was observed.

The growth regulator trinexapac-ethyl reduced the height, shoot dry matter, and lodging of plants when the conditions were favorable for greater growth, without changing the productive performance of wheat.

In the cultivation of wheat in succession to soybeans, a greater dose of $\mathrm{N}$ increases the height, productivity of grains, and $\mathrm{N}$ accumulated in the whole plant and grains.

\section{Acknowledgements}

À FUNARBE - Fundação Arthur Bernardes pelo auxílio financeiro à pesquisa, ao CNPq pela concessão de bolsas IC ao primeiro e quarto autores, à FAPEMIG pela bolsa IC concedida ao terceiro autor e, à COOPADAP - Cooperativa Agropecuária do Alto Paranaíba pela área experimental utilizada.

\section{References}

ALBRECHT, J. C.; SILVA, M. S.; ANDRADE, J. M. V.; SCHEEREN, P. L.; TRINDADE, M. G.; SOARES SOBRINHO, J.; SOUSA, C. N. A.; BRAZ, A. J. B. P.; RIBEIRO JÚNIOR, W. Q.; SOUSA, M. A.; FRONZA, V.; YAMANAKA, C. H. Trigo BRS 264: cultivar precoce com alto rendimento de grãos indicada para o Cerrado do Brasil Central. Planaltina: Embrapa Cerrados, 2006. 21 p. (Documentos, Embrapa Cerrados, 174).

ARGENTA, G.; SILVA, P. R. F.; BORTOLINI, C. G. Clorofila na folha como indicador do nível de nitrogênio em cereais. Ciência Rural, Santa Maria, v. 31, n. 4, p. 715-722, 2001

CRUZ, P. J.; CARVALHO, F. I. F.; CAETANO, V. R.; SILVA, S. A.; KUREK, A. J.; BARBIERI, R. L. Caracteres relacionados com a resistência ao acamamento em trigo comum. Ciência Rural, Santa Maria, v. 31, n. 4, p. 563-568, 2001.

DAVIES, P. J. Plant hormones and their role in plant growth and development. In: (Ed.). The plant hormones: their nature, occurrence, and functions. The Netherlands: Kluwer Academic, 1987. p. 1-23.

FIOREZE, S. L.; RODRIGUES, J. D. Componentes produtivos do trigo afetados pela densidade de semeadura e aplicação de regulador vegetal. Semina: Ciências Agrárias, Londrina, v. 35, n. 1, p. 39-54, 2014.

FORNASIERI FILHO, D. Manual da cultura do trigo. Jaboticabal: Funep, 2008. 336 p.

MEGDA, M. M.; BUZETTI, S.; ANDREOTTI, M.; TEIXEIRA FILHO, M. M. C.; VIEIRA, M. X. Resposta de cultivares de trigo ao nitrogênio em relação às fontes e épocas de aplicação sob plantio direto e irrigação por aspersão. Ciência e Agrotecnologia, Lavras, v. 33, n. 4, p. 1055-1060, 2009. 
MALAVOLTA, E.; VITTI, G. C.; OLIVEIRA, S. A. Avaliação do estado nutricional das plantas: princípios e aplicações. 2. ed. Piracicaba: Associação Brasileira para Pesquisa da Potassa e do Fosfato, 1997. 319 p.

MARCO JUNIOR, J.; CORREIA, D.; NAKAI, E. H. Efeito do regulador de crescimento trinexapac-ethyl na produtividade de trigo. Acta Iguazu, Cascavel, v. 2, n. 1, p. 14-19, 2013.

MEGDA, M. M.; BUZETTI, S.; ANDREOTTI, M.; TEIXEIRA FILHO, M. M. C.; VIEIRA, M. X. Resposta de cultivares de trigo ao nitrogênio em relação às fontes e épocas de aplicação sob plantio direto e irrigação por aspersão. Ciência e Agrotecnologia, Lavras, v. 33, n. 4, p. 1055-1060, 2009.

NOVAIS, G. T. Caracterização climática da mesorregião do Triângulo Mineiro/Alto Paranaíba e da Serra da Canastra (MG). 2011. Dissertação (Mestrado em Geografia) - Universidade Federal de Uberlândia, Uberlândia.

NUNES, P. M. P.; AQUINO, L. A.; SANTOS, L. P. D.; XAVIER, F. O.; DEZORDI, L. R.; ASSUNÇÃ̃, N. S. Produtividade do trigo irrigado submetido à aplicação de nitrogênio e à inoculação com Azospirillum brasilense. Revista Brasileira de Ciência do Solo, Viçosa, MG, v. 39, n. 1, p. 174-182, 2015.

PAGLIOSA, E. E.; BENIN, G.; BIEZUS, E.; BECHE, E.; SILVA, C. L.; MARCHESE, J. A.; MARTIN, T. N. Trinexapac-ethyl e adubação nitrogenada na cultura do trigo. Planta Daninha, Viçosa, MG, v. 31, n. 3, p. 623630, 2013.

PENCKOWSKI, L. H. Efeitos do trinexapac-ethyl e do nitrogênio na produtividade da cultura do trigo. 2006. Dissertação (Mestrado em Agronomia) - Universidade Estadual de Ponta Grossa, Ponta Grossa.

PENCKOWSKI, L. H.; FERNANDES, E. C. Utilizando regulador de crescimento na cultura de trigo: aspectos importantes para garantir bons resultados. 3. ed. Castro: Fundação ABC, 2010. 68 p.

PENCKOWSKI, L. H.; ZAGONEL, J.; FERNANDES, E. C. Qualidade industrial do trigo em função do trinexapacethyl e doses de nitrogênio. Ciência e Agrotecnologia, Lavras, v. 34, n. 6, p. 1492-1499, 2010.

PRANDO, A. M.; ZUCARELI, C.; FRONZA, V.; BASSOI, M. C.; OLIVEIRA, F. A. Formas de ureia e doses de nitrogênio em cobertura no desempenho agronômico de genótipos de trigo. Semina: Ciências Agrárias, Londrina, v. 33, n. 2, p. 621-632, 2012.

RADEMACHER, W. Growth retardants: effects on gibberellin biosynthesis and other metabolic pathways. Annual Review of Plant Physiology and Plant Molecular Biology, Palo Alto, v. 51, n. 1, p. 501-531, 2000.
RAJALA, A. Plant growth regulators to manipulate cereal growth in Northern growing conditions. 2003. Dissertation (Academic Master in Agriculture and Foresty) - Faculty of Agriculture and Forestry. University of Helsinki, Helsinki.

RODRIGUES, L. F. O. S.; GUIMARÃES, V. F.; SILVA, M. B.; PINTO JUNIOR, A. S.; KLEIN. J.; COSTA, A. C. P. R. Características agronômicas do trigo em função de Azospirillum brasilense, ácidos húmicos e nitrogênio em casa de vegetação. Revista Brasileira de Engenharia Agrícola e Ambiental, Campina Grande, v. 18, n. 1, p. 31-37, 2014.

TAIZ, L.; ZEIGER, E. Fisiologia vegetal. 4. ed. Porto Alegre: Artmed, 2009. 820 p.

TEIXEIRA FILHO, M. C. M.; BUZETTI, S.; ANDREOTTI, M.; ARF, O.; BENETT, C. G. S. Doses, fontes e épocas de aplicação de nitrogênio em trigo irrigado em plantio direto. Pesquisa Agropecuária Brasileira, Brasília, v. 45, n. 8, p. 797-804, 2010.

VALÉRIO, I. P.; CARVALHO, F. I. F.; OLIVEIRA, A. C.; BENIN, G.; SOUZA, V. Q.; MACHADO, A. A.; BERTAN, I.; BUSATO, C. C.; SILVEIRA, G.; FONSECA, D. A. R. Seeding density in wheat genotypes as a function of tillering potential. Scientia Agricola, Piracicaba, v. 66, n. 1, p. 28-39, 2009.

ZAGONEL, J.; FERNANDES, E. C. Doses e épocas de aplicação de redutor de crescimento afetando cultivares de trigo em duas doses de nitrogênio. Planta Daninha, Viçosa, MG, v. 25, n. 2, p. 331-339, 2007.

ZAGONEL, J.; FERNANDES, E. C.; KORELLO, $S$. Efeitos de regulador de crescimento (trinexapacethyl) da irrigação e da dose de nitrogênio na cultura do trigo. In: REUNIÃO DA COMISSÃO CENTRO SUL BRASILEIRA DE PESQUISA DE TRIGO, 2005, Londrina. Anais... Londrina: Embrapa Soja, 2005. p. 130-134.

ZAGONEL, J.; KUNZ, R. P. Doses de nitrogênio e de regulador de crescimento (Moddus) afetando o trigo. In: REUNIÃO DA COMISSÃO CENTRO SUL BRASILEIRA DE PESQUISA DE TRIGO, 2005, Londrina. Anais... Londrina: Embrapa Soja, 2005. p. 135-140.

ZAGONEL, J.; VENANCIO, W. S.; KUNZ, R. P. Efeito de regulador de crescimento na cultura do trigo submetido a diferentes doses de nitrogênio e densidade de plantas. Planta Daninha, Viçosa, MG, v. 20, n. 3, p. 471-476, 2002a.

ZAGONEL, J.; VENANCIO, W. S.; KUNZ, R. P.; TANAMATI, H. Doses de nitrogênio e densidades de plantas com e sem um regulador de crescimento afetando o trigo, cultivar OR 1. Ciência Rural, Santa Maria, v. 32, n. 1, p. 25-29, 2002b. 